\title{
Pemodelan Sistem Data Terdistribusi Untuk Mengintegrasikan Data Akademik Dan Keuangan
}

\author{
Arik Sofan Tohir \\ STMIK AMIKOM YOGYAKARTA \\ Yogyakarta, Indonesia \\ E-mail: arik.sofan.tohir@gmail.com
}

\begin{abstract}
Data merupakan sesuatu yang sangat penting khusus nya untuk kebutuhan sebuah perusahaan atau organisasi, dimana dari data tersebut bisa mengasilkan suatu informasi yang bermanfaat bagi perusahaan atau organisasi tersebut sebagai bahan untuk pengembangan maupun untuk bahan analisis data sebagai dasar untuk pengambilan keputusan. Dengan perkembangan dunia teknologi digital yang semakin berkembang saat ini, data-data yang semula disimpan dalam bentuk kertas sekarang bisa di simpan dalam bentuk digital dengan memanfaatkan database engine. Jika suatu perusahaan atau organisasi yang sudah memiliki data yang tersebar dibeberapa tempat yang terpisah atau dikeembangkan dengan beberapa jenis platform software yang berbeda. Tentu diperlukan suatu teknik untuk mengintegrasikan data dari beberapa tempat yang berbeda dan menggunakan beberapa jenis platform software yang berbeda. Dengan ada nya integrasi data ini dimungkinkan untuk menggabungkan data-data yang terpisah di beberapa tempat dan menggunakan beberapa jenis platform software yang berbeda.
\end{abstract}

Kata Kunci-Database Engine, Integrasi data, platform software, UML

\section{Pendahuluan}

Informasi yang berkualitas, akurat, dan cepat dalam penyajian nya tentu akan sangat bermanfaat bagi suatu perusahaan atau organisasi, dimana data-data tersebut bisa diolah menjadi informasi yang bermanfaat dan bisa digunakan sebagai alat untuk mengembangkan atau sebagai dasar organisasi atau perusahaan tersebut untuk menentukan sebuah kebijakan dalam pengambilan keputusan. Untuk mengolah data-data yang ada pada sebuah organisasi atau perusahaan tentu nya tidak lepas dari software pengolah data untuk menghasilkan informasi. Berbagai sofware pengolah data dari mulai berbasis desktop (desktop base), berbasis web (web base) maupun berbasis mobile (mobile base). Dan sebuah sistem tentu nya tidak lepas dari database engine yang berfungsi untuk menampung data-data yang ada.

Dengan ada nya berbagai macam jenis teknologi platform yang berbeda, tentu nya perlu suatu teknik untuk bisa mengintegrasikan data-data yang terpisah. Salah satu cara yang bisa digunakan untuk 
mengolah data yang terpisah dan memiliki beberapa teknologi yang berbeda. Penerapan sistem terdistribusi dipilih karena memiliki kemampuan penyebaran informasi dan pembagian sumber daya yang efektif, luas, efisien serta memiliki banyak macam teknologi [1].

Sistem basis data terdistribusi merupakan suatu bentuk arsitektur sistem dimana data-data yang berdiri secara otonom dapat saling bertukar informasi dan berbagi resource tanpa memperdulikan lokasi dimana data tersebut berada dan platform yang digunakan[2]. Dengan adanya keunggulan data terdistribusi tersebut, maka dalam penelitian ini akan dibuat sebuah pemodelan datat untuk mengintegrasikan data yang memiliki beberapa platform yang berbeda.

\section{Metode Penelitian}

Dalam penelitain ini untuk membuat pemodelan sistem data terdistribusi akan menggunakan pendekatan secara obyek untuk membuat kebutuhan sistem. Sebagai sebagai subyek untuk membuat pemodelan sistem data terdistribusi akan menggunakan sistem informasi yang bergerak dalam dunia pendidikan, yang meliputi data keuangan dan data akademik dari masing-masing kantor cabang. Dimana dalam pendekatan secara obyek ini akan menggunakan beberapa diagram yang digunakan dalam Unified Modelling Languange (UML). UML adalah bahasa pemodelan yang standar untuk lingkungan berorientasi obyek, yang berisi notasi notasi grafis yang relative sudah dibakukan (open standard) [3]. Dengan menggunakan pendekatan secara obyek akan didapatkan sebuah pemodelan sistem yang lebih spesifik dengan kebuuhan user. UML yang terdiri dari serangkaian diagram memungkinkan bagi sistem analis untuk membuat cetak biru sistem yang komprehensif kepada clien, programer dan tiap orang yang terlibat dalam proses pengembangan tersebut. Dengan UML akan bisa menceritakan apa yang seharus nya dilakukan oleh sebuah sistem bukan bagaimana yang seharus nya sistem dilakukan oleh sebuah sistem[4].

\section{Hasil \& Pembahasan}

Untuk menghasilkan sebuah informasi yang bermfaat diperlukan beberapa langkah yaitu langkah input data, pengolahan data dan akhir nya akan menghasilkan sebuah informasi yang disajikan dalam laporan-laporan yang diperlukan. Pemodelan sistem data terdistribusi akan di modelkan menggunakan Unified Modelling Languange (UML) untuk mediskripsikan objek-objek, proses dan aturan-aturan yang ada dalam pemodelan sebuah sistem. Dalam penelitain ini akan menggunakan beberapa diagram yang ada pada Unified Modelling Languange (UML) diantara nya diagram use case, diagram activity (Activity Diagram), diagram sequence (Sequnce Diagram), diagram Class (Class Diagram).

Use Case adalah deskripsi fungsi dari sebuah sistem dari perspektif pengguna. Use case bekerja dengan cara mendeskripsikan tipikal interaksi antara user (pengguna) sebuah sistem dengan sistem nya sendiri 
melalui sebuah cerita bagiamana sebuah sistem dipakai. Urutan langkah-langkah yang menerangkan anatara pengguna dan sistem disebut scenario. Setiap scenario mendeskripsikan urutan kejadian. Setiapa urutan diinisialisasi oleh orang, sistem yang lain, perangkat keras maupun urutan waktu [4].

Sequence diagram digunakan untuk menggambarkan perilaku pada sebuah scenario. Diagram ini menunjukkan sejumlah contoh obyek dan message (pesan) yang diletakkan diantara obyek-obyek ini dalam use case. Activity diagram adalah teknik untuk mendeskripsikan logika prosedural, proses bisnis dan aliran kerja dalam banyak kasus. Activity diagram mempunyai peran seperti halnya flowchart, akan tetapi perbedaan nya dengan flowchart adalah activity diagaram bisa mendukung perilaku paralel sedangkan flowchart tidak bisa. [4]. Untuk pemodelan sistem data terdistribusi untuk mengintegrasikan data ditunjukkan pada gambar 1 .

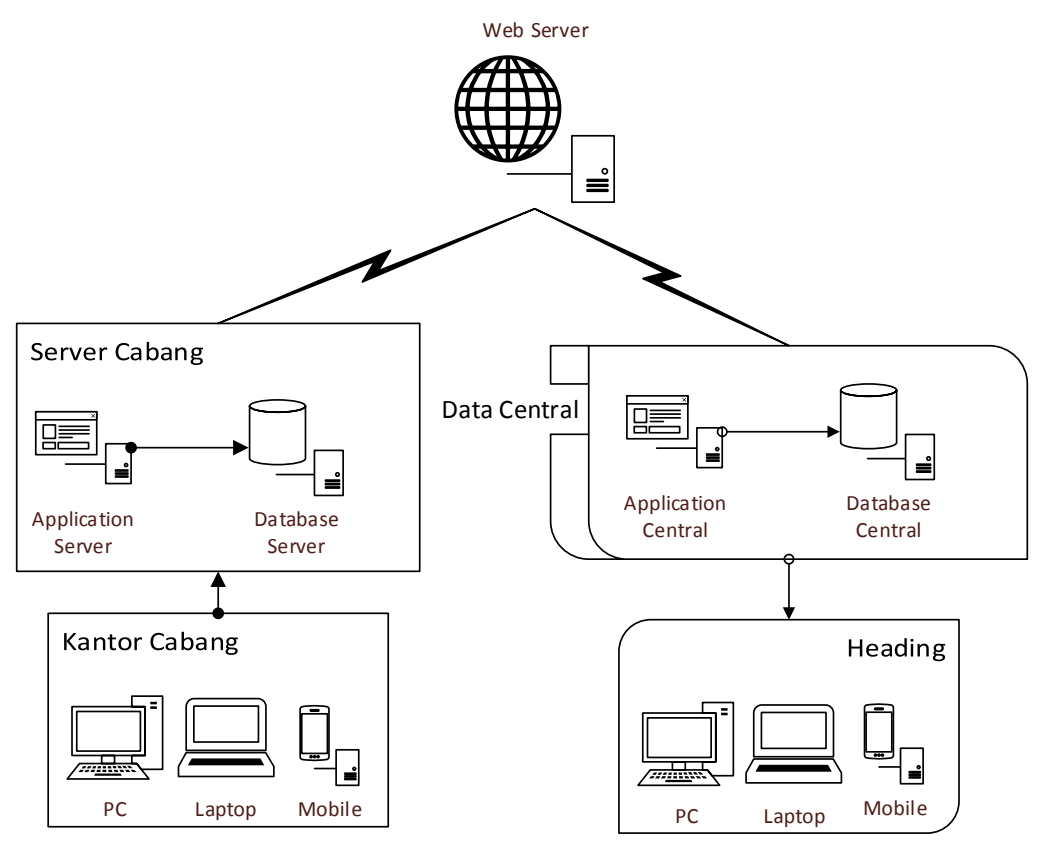

\section{GAMBAR I. DESAIN KomUniKasi DATA ANTAR KANTOR CABANG DAN PUSAT}

Pada gambar 1 digambarkan bagaimana sistem saling berinteraksi dengan sistem yang lain. Setiap masing-masing cabang memiliki dua sistem yaitu sistem untuk menginput data-data traksaksi yang ada pada cabang, dimana hasil data-data ini disimpan diserver masing-masing cabang. Dari server cabang ini terdapat sebuah sistem yang bertugas untuk mengirimkan data atau berkomunikasi dengan server pusat dengan memanfaatkan web server, dengan memanfaatkan web server data-data yang dikirim oleh cabang diintegrasikan dengan data central yang ada pada kantor pusat. Sehingga dengan ada nya integrasi data ini semua data yang ada pada masing-masing cabang disimpan pada data central yang ada pada kantor pusat data bisa diakses dengan cepat oleh kantor pusat karena kantor pusat tidak perlu lagi untuk mengambil data yang ada di masing-masing cabang. Dari gambar 1 juga terlihat bahwa data disimpan pada dua tempat yaitu diserver masing-masing cabang dan di server data central, hal ini sangat penting untuk menghindari kehilangan data karena dengan model sistem seperti pada gambar 1 
Jurnal INTENSIF, Vol.1, No.1, Februari 2017

ISSN: $2549-6824$

masing-masing cabang memiliki data backup. Selain itu juga untuk mendapatkan performas yang maksimal dalam pengolahan data karena pengaolahan data awal di lakukan dimasing-masing server kantor cabang dan tidak membebani server data central. Setelah data masing-masing cabang diinput dan diproses maka data akan dikirim ke server data central.

Untuk pemodelan sistem informasi akan dibuat dengan dua model yaitu pemodelan sistem untuk kebutuhan kantor cabang dan kebutuhan sistem untuk kebutuhan kantor pusat atau kebutuhan sistem untuk mengintegrasikan data yang ada dimasing-masing cabang. Gambar 2 menunjukkan desain siste untuk kebutuah dimasing-masing cabang.

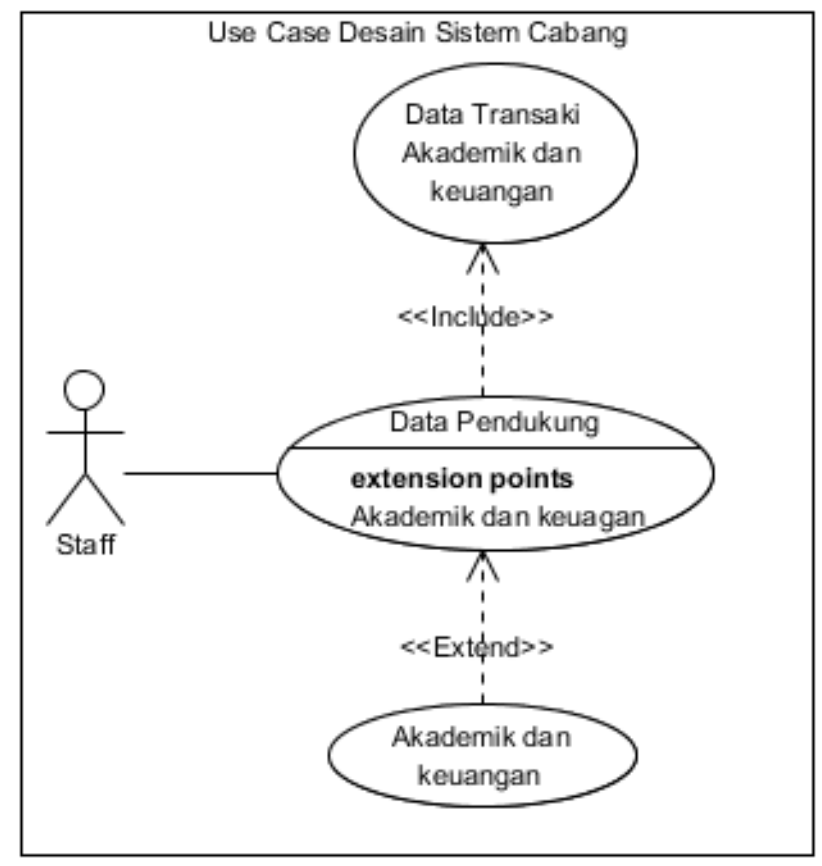

\section{GAMBAR II. DESAIN SiSTEM UNTUK KANTOR CABANG}

Pada gambar 2 menunjukkan kebutuhan sistem yang ada pada masing-masing cabang. Dimana setiap staff atau pegawai yang ada pada masing-masing cabang bertugas untuk menginputkan data-data yang ada pada masing-masing cabang. Data-data yang dimasukkan setiap kantor cabang adalah data yang terkait dengan data akademik dan keuangan. Untuk desain sistem yang ada pada data pusat atau data central ditunjukkan pada gamabar 3. 


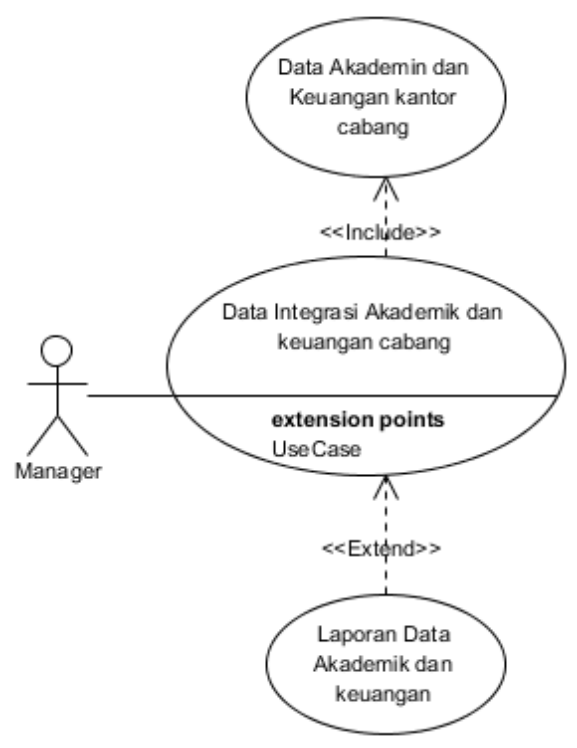

\section{GAMBAR III. DESAIN SiSTEM KANTOR PUSAT}

Pada gambar 3 menunjukkan kebutuhan desain sistem yang ada pada kantor pusat yang bertindak sebagai data central dari semua cabang. Pada sistem pusat data didapatkan dari masing-masing cabang sehingga seorang manager yang bertindak sebagai pengambil keputusan dan menentukan kebijakan bisa mendapatkan laporan tanpa harus datang ke masing-masing cabang karena data semua cabang sudah terpusat disatu server.

Untuk pemodelan komunikasi data antara kantor cabang dan pusat dintunjukkan pada gambar 4. Pada gambar 4 menjelaskan gambaran pemodelan sistem yang saling berinteraksi antara sistem yang ada pada kantor cabang dengan kantor pusat yang bertindak sebagai pusat data.

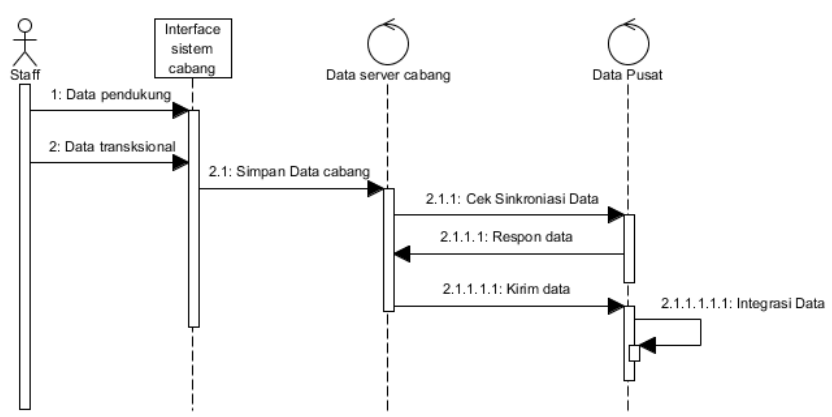

\section{GAMBAR IV. SEQUENCE Diagram Komunikasi Sistem CABANG DAN PUSAT}

Gambar 4 merupkan gambaran desain sistem untuk berkomunikasi antara cabang dan pusat dalam proses integrasi data. Seorang staff atau pegawai di masing-masing cabang menginputkan data, baik data-data pendukung maupun data-data transaksional yang terjadi di masing-masing cabang. Selanjut nya data disimpan pada masing-masing server pada setiap cabang. Pada bagian server cabang akan melaksakan proses untuk intgrasi data dengan data pusat. Untuk melakukan proses integrasi data dari cabang kepusat terdapat beberapa proses yang dijalankan pada masing-masing server yang ada pada kantor cabang. Pertama server cabang yang bertindak sebagai penampung data disetiap cabang dan 
sekaligus bertindak sebagai pelayanan untuk integrasi data melakukan proses pengecekan apakah data yang ada pada sisi data cabang sudah tersedia pada sisi server pusat, proses ini memastikan data-data yang akan dikirim dari cabang ke server benar-benar data yang valid dan sudah terverifikasi. Proses selanjut nya setelah mendapatkan data-data yang terverifikasi maka data-data yang belum tersedia diserver pusat dilakukan proses pengiriman data dari server kantor cabang ke server pusat. Selanjut nya dari proses pengiriman data dari kantor cabang, server pusat akan melakukan proses integrasi data. Dengan proses ini data-data yang ada pada masing-masing cabang disimpan pada data pusat. Dari hasil integrasi data ini seorang manager untuk mengontrol laporan atau mengontrol data-data yang ada pada masing-masing cabang cukup dengan memanfaatkan data yang sudah tersimpan pada data central.Untuk memodelkan alur logika secara prosedural yang terjadi dalam proses bisnis yang ada pada sistem integrasi data akan digambarkan dengan menggunakan salah satu jenis diagram yang ada pada pemodelean obyek Unified Modelling Languange (UML) yaitu activity diagram. Pada gambar 5 menunjukkan alur logika untuk input data pendukung dan transksaksi yang berjalan pada sisi kantor cabang.

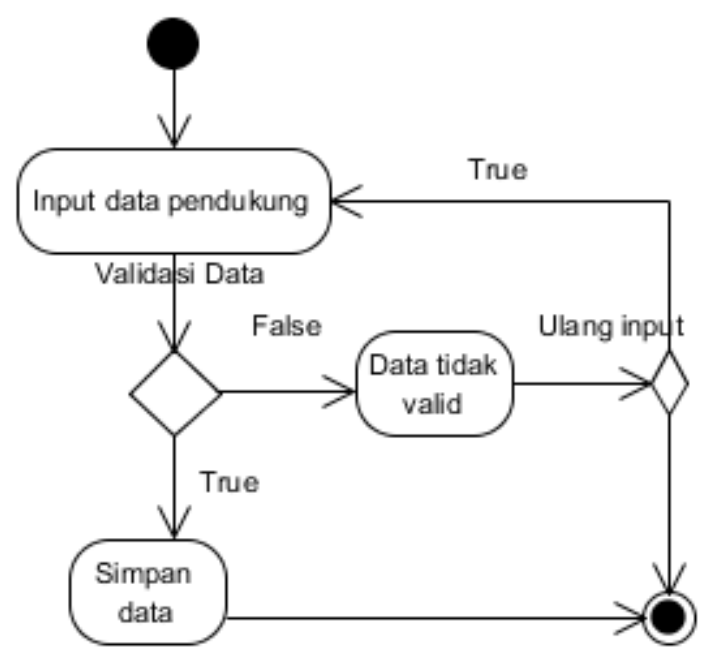

\section{GAMBAR V. ACTIVITy DiagRAM DATA PENDUKUng}

Pada gambar 5 menunjukkan proses alur untuk menginputkan data pendukung yang ada pada kantor cabang. Terlihat dalam Activity Diagram tersebut data pendukung yang akan disimpan kedalam data dilakukan validasi terlebih dahulu. Hal ini sangat penting untuk memastikan data yang dimasukkan dan yang disimpan benar-benar merupakan data yang valid dan benar, sehingga nanti nya data yang akan dikirim ke server pusar adalah data yang bisa dipertanggung jawabkan kevalidan data nya. Pada gambar 6 menunjukkan alur proses untuk input data transaksi yang terjadi pada sistem pada masing-masing cabang. 


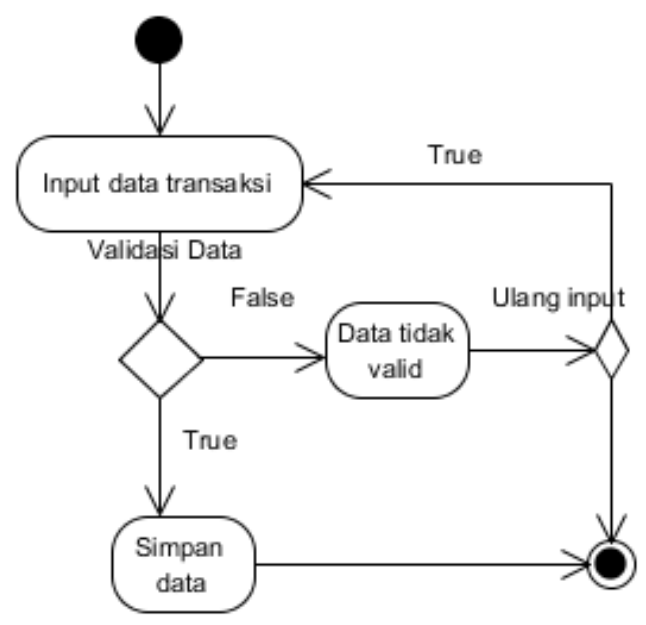

\section{GAMBAR VI. DIAGRAM ACTIVITY DATA TRANSAKSI}

Proses input data transaksi yang ditunjukkan pada gambar 6 tidak jauh berbeda dengan input data transaksional, dimana pada proses ini juga ada valadisa data yang berfungsi untuk memverifikasi data yang akan disimpan dan memastikan bahwa data terserbut benar-benar valid sebelum data transaksi tersebut di kirim ke data central untuk dilakukan proses intgrasi data. Desain berikut nya yang tidak kalah penting adalah desain sistem untuk ada keterkaitan ny dengan penyimpanan data. Dalam pendekan dengan obyek desain sistem ini memanfaatkan Class Diagram yang merupakan salah satu cara untuk memodelkan desain yang terkait dengan database. Pada gambar 7 menunjukkan desain sistem kebutuhdan database untuk akademik.

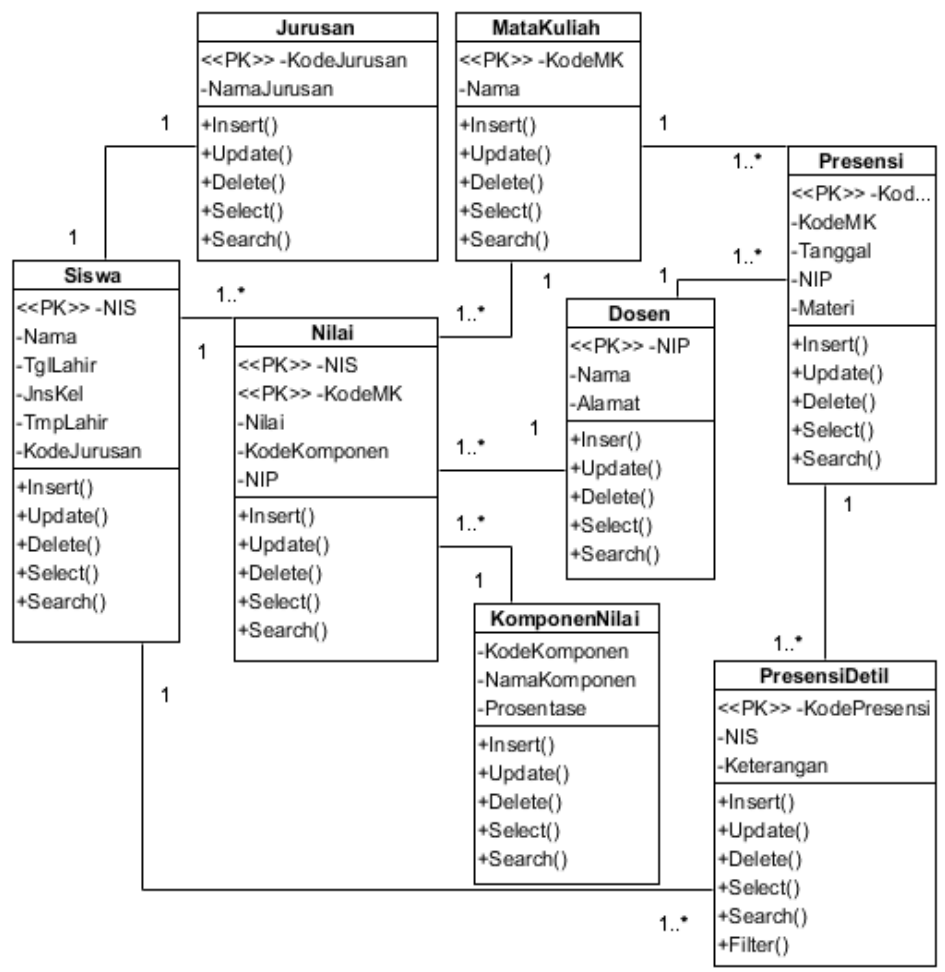

GAMBAR VII. Class DiagRam SISTEM AKADEMIK 
Class diagram yang ditunjukkan pada gambar 7 merupakana pemodelan class diagram untuk kebutuhan akademik. Dari masing-masing class diagram memiliki association / asosiasi dengan class yang lain. Dengan adanya asosiasi antar class, semua class akan terhubung menjadi satu kesatuan sistem yang utuh. Dari class diagram yang terbentuk inilah yang nanti nya akan dijadikan sebagai acuan untuk mengitegrasikan data-data yang ada pada kantor cabang dengan data yang ada pada kantor pusat. Dengan adanya kesamaan model desain kebutuhan class diagram pada masing-masing sistem, baik sistem yang ada pada cabang atau pusat akan memudahkan untuk melakukan proses integrasi data. Selain itu juga akan memudahkan dalam pengembangan sistem lebih lanjut.

Dari class diagram pada gambar 7 secara garis besar dapat dibagi menjadi dua bagian yaitu class diagram untuk data penduduk dan class diagram untuk data transaksi akademik. Untuk class yang termasuk dalam bagian class pendukung meliputi class jurusan, class siswa, class dosen, class mata kuliah dan class komponen nilai. Class ini termasuk dalam class pendukung karena secara prinsip classclass ini dapat berdiri sendiri dan memiliki makna tanpa memerlukan class yang lain.

Sedangkan yang termasuk dalam bagian class transaksi adalah class presensi, class presensi detil, dan class nilai. Class-class ini termasuk class transaksi karena class ini tidak dapat berdiri sendiri, artinya untuk membuat class ini menghasilkan informasi yang bermakna dan memiliki arti memerlukan asosiasi dengan class-class yang lain. Untuk desain pemodelan sistem yang terkait dengan transksi keuangan akan ditunjukkan pada gambar 8 .

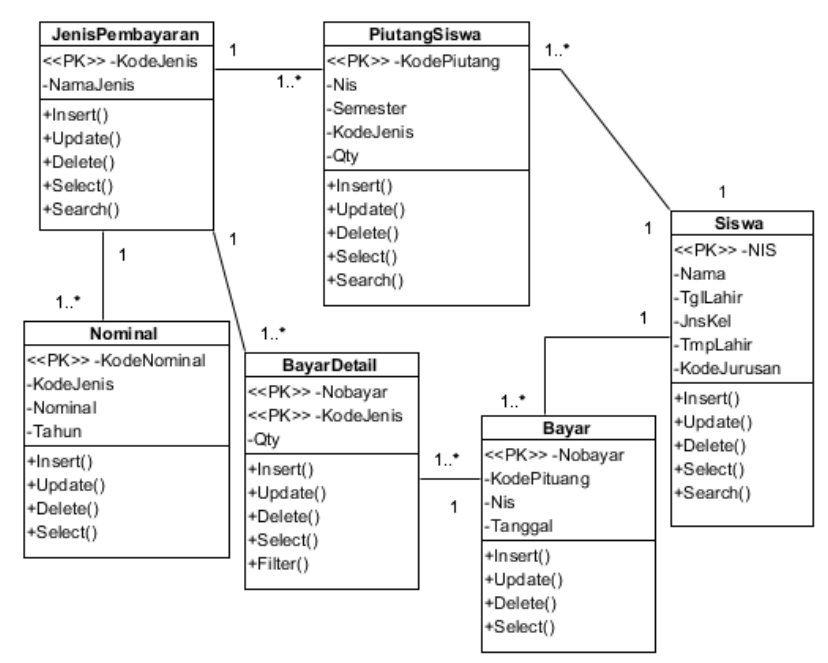

\section{GAMBAR VIII. Class Diagram DESAin KeUANGAN}

Sama hal nya dengan class diagram pada gambar 7, class diagram yang ditunjukkan pada gambar 8 juga dapat dikategorikan menjadi dua bagian yaitu bagian class untuk data pendukung dan class untuk data transaksi. Yang trmasuk dala bagian data class pendukung adalah jenis pembayaran dan siswa. Sedangkan selebihnya merupakan jenis class yang termasuk dalam class transaksi.

Untuk hasil pembuatan pemodelan sistem integrasi data salah satu nya memanfaatkan stored procedure untuk membentuk standarisasi proses integrasi. Dengan memanafaatkan stored procedure yang dijalankan pada sisi database engine akan menghasilkan performa yang lebih stabil dan meminimalisir 
kesalahan. Selain itu stored procedure juga sudah mendukung berbagai jenis platform software bahasa pemrograman, untuk hasil stored procedure nya ditunjukkan pada gambar gambar 9.

\begin{tabular}{|c|c|c|}
\hline Po bayar_chek & P() Jurusan_view & P() piutangsiswa_view \\
\hline P() bayar_delete & P() komponen_nilai_chek & P) presensi_chek \\
\hline Po bayar_insert & P() komponen_nilai_delete & P() presensi_delete \\
\hline fobayar_key & P) komponen_nilai_insert & P) presensi_detil_chek \\
\hline P() bayar_update & fo komponen_nilai_key & Po presensi_detil_delete \\
\hline P() bayar_view & P) komponen_nilai_update & P) presensi_detil_insert \\
\hline Po bayardetil_chek & P() komponen_nilai_view & $f_{f}$ presensi_detil_key \\
\hline P() bayardetil_delete & P() matakuliah_chek & P) presensi detil update \\
\hline Po bayardetil_insert & P() matakuliah_delete & P() presensi_detil_view \\
\hline$f_{\text {() }}$ bayardetil_key & Po) matakuliah_insert & Po presensi_insert \\
\hline P) bayardetil_update & $\left.f_{(}\right)$matakuliah_key & fo presensi_key \\
\hline P() bayardetil_view & P() matakuliah_update & P() presensi_update \\
\hline P() dosen_chek & P() matakuliah_view & P() presensi_view \\
\hline P() dosen_delete & P() Nilai_chek & P() Siswa_chek \\
\hline P() dosen_insert & P) Nilai_delete & P() Siswa_delete \\
\hline$\left.f_{f}\right)$ dosen_key & Po Nilai_insert & P) Siswa_insert \\
\hline P() dosen_update & foNilai_key & $f_{(/)}$Siswa_key \\
\hline P() dosen_view & P() Nilai_update & P() Siswa_update \\
\hline Po jenis_pembayaran_chek & P() Nilai_view & P() Siswa_view \\
\hline P( jenis_pembayaran_delete & P() nominal_chek & \\
\hline P( ) jenis_pembayaran_insert & P() nominal_delete & \\
\hline$f_{\text {() jenis_pembayaran_key }}$ & P() nominal_insert & \\
\hline P() jenis_pembayaran_update & f() nominal_key & \\
\hline P( ) jenis_pembayaran_view & P() nominal_update & \\
\hline P() Jurusan_chek & P() nominal_view & \\
\hline P() Jurusan_delete & P() piutangsiswa_chek & \\
\hline$P()$ Jurusan_find & P() piutangsiswa_delete & \\
\hline P() Jurusan_insert & Po) piutangsiswa_insert & \\
\hline$\left.f_{f}\right)$ Jurusan_key & $f_{\text {/ }}$ piutangsiswa_key & \\
\hline P() Jurusan_update & P() piutanqsiswa_update & \\
\hline
\end{tabular}

GAMBAR IX. STORED PROCEDURE

\section{KeSIMPUlan \& SARAN}

Dari hasil pemodelan sistem integrasi data dapat disimpulkan bahwa data dapat diintegrasikan dengan baik. Dengan pendekatan obyek dapat dihasilkan sebuah model sistem integrasi data dengan menghasilkan desain sistem berupa use case diagram, activity diagram, sequence diagram dan class diagram. Untuk kedepan nya sistem ini bisa dikembangkan untuk sistem keuangan yang meliputi akuntansi, sehingga akan didapatkan sebuah sistem informasi yang lengkap dalam sebuah organisasi pendidikan. Selain itu sistem ini bisa dikembangkan juga untuk pemodelan data warehouse.

\section{DAFTAR PUStaka}

[1] Adinandra Dharmasurya, Teguh Wahyono, Ramos Somya, "Pengembangan Sistem Terdistribusi Untuk Sistem Informasi Administrasi Kependudukan Dengan Integrasi Teknologi RMI dan Web Service”, Jurnal Teknologi Informasi-Aiti, Vol. 10. No.1, Februari 2013 : 1-100.

[2] Ahmad Haidar Mirza, "Perancangan Basis Data Terdistribusi E-CARGO (Studi Kasus PT. XYZ)", Seminar Nasional Informatika, UPN ”Veteran” Yogyakarta, 18 Juni 2013.

[3] Febri Nova Lentil, "Rekayasa Database Terdistribusi Pada Layanan Pemesanan Tiket Pesawat Terbang" Jurnal Teknologi Technoscientia, Vol. 6 No. 2 Februari 2014.

[4] Munawar, "Pemodelan Visual Dengan UML”, Graha Ilmu Edisi Pertama, 2005. 